\title{
(Nearly) Outside the Shadow of Hierarchy: An Enquiry into the Teleology of Municipal Paradiplomacy in the EU
}

\author{
Elisabetta Mocca \\ Department of Sociology, University of Vienna, Vienna, Austria \\ elisabetta.mocca@univie.ac.at
}

Received: 13 June 2019; revised: 13 January 2020; accepted: 29 March 2020

\section{Summary}

Local authorities have increasingly deployed instruments and practises proper of the international diplomatic repertoire-a phenomenon referred in the literature as paradiplomacy. These state-like diplomatic praxes, ranging from participating in transnational networks to signing international agreements, hint at an increased room for manoeuvre for local authorities, in that they occur without the intervention and control of the central state. While emulating states' international behaviour, municipal paradiplomacy displays distinctive features and purposes. Drawing on the scholarship on paradiplomacy, this article provides a theoretical reflection on the teleology of municipal paradiplomatic practices. By proceeding through parallelism with state diplomacy's objectives, this article identifies three functional equivalents that constitute the primary teloi of paradiplomacy; namely, municipal self-determination, influence and contention. By delving into the aims of municipal paradiplomacy, the article points out how municipal paradiplomacy constitutes a valuable means for municipalities to progressively free themselves from the grip of the central state.

\section{Keywords}

paradiplomacy - municipalities - European Union (EU) - teleology 
Thirty years ago, Ivo D. Duchacek peremptorily asserted that international activities of noncentral governments rarely make the first page of national dailies.' ${ }^{1}$ To date, this statement no longer reflects the political role of local authorities: once neglected actors in the Grand Politics of international affairs, local authorities appear to have made their way out of the oblivion. Going beyond the loose relations of the 2oth century's ententes amicales, now local authorities deploy instruments and practices proper of the international diplomatic repertoire. This is especially true in Europe, where cities have engaged in a swath of state-like activities, including the creation of and participation in town twinning, networks and 'multilateral organisations', as well as the signature of 'bilateral cooperation agreements'.

The return of cities on the political scene has rekindled the scholarly interest for the urban dimension. Local authorities have come to be understood by scholars and commentators as fully-fledged governing units, distinctive from nation states, endowed of their own decision-making capacity and embedded in a specific political, socio-economic and cultural context. This characterisation of cities is evident in the terminology employed in political science, geography, and urban studies. Terms such as 'actors', 'players', 'policymakers' -instead of 'policy-takers,', $3,4,5$ as implicitly assumed by much of state-centred theories - are just but few examples of epitomes used to underscore the proactive political role of cities. Especially in the European Union (EU), local authorities have been able to restore their political influence, developing relations with other European cities and with the EU through interurban organisations such as the Council of European Municipalities and Regions, or networks such as Eurocities.

The increased capacity of cities to act freely on the international arena has elicited theorisations likening the international behaviours and practices of cities to those of states, leading to the coinage of the term paradiplomacy. This concept may be defined as a 'mature political practice, encompassing all aspects of a true diplomatic culture, including the search for agreement

1 Duchacek 1987, 2.

2 La Porte 2013, 90.

3 Kern 2009, 1.

4 Le Galès and Harding 1998, 122.

5 See Le Galès 2002, 7, defining the city as a 'collective actor'.

6 Schultze 2003, 121. 
or consensus, but also the sometimes aggressive quest for self-interest at the detriment of others. ${ }^{7}$

Following the seminal work of Duchacek ${ }^{8}$ and Panayotis Soldatos, ${ }^{9}$ the paradiplomatic activities of subnational authorities have been documented by a sizeable host of research..$^{10}$ Nevertheless, the contribution of International Relations has been scant. ${ }^{11}$ The literature on paradiplomacy suggests that supranational municipal engagement is the outcome of an increased capacity of cities to act independently from the central state, engendered by top-down and bottom-up drivers. On the one hand, it is argued that decentralisation, internationalisation and, within the EU, European integration granted municipalities a greater capacity to act more freely at international level. On the other hand, the research contributions on the topic emphasise subnational authorities' political agency, highlighting how the direct and seemingly uncontrolled involvement of cities in international political arenas expand their room for manoeuvre, consolidating their capacity to act as autonomous political agents.

On closer examination, the paradiplomacy scholarship is primarily concerned with the diplomatic activity of substates entities; that is, regions and federated states. ${ }^{12}$ Surely, the prevalence of studies on regions is motivated by the fact that the latter are endowed of legal powers and have fairly homogenous socio-economic and cultural conditions-drivers that may trigger separatist claims (as in the case of Catalonia, Scotland and Quebec). Nonetheless, there is a growing scholarly interest on diplomatic-like practices undertaken by local authorities. ${ }^{13}$ Among this latter thread of research, the paradiplomatic practices and international presence of global cities has drawn a great deal of interest. ${ }^{14}$ However, comparatively less attention has been given to non-capital cities' activities such as second- and third-tier localities. Although the lion's share of municipal actors engaged in international activities is constituted by the aforementioned types of local authorities, the international engagement

\footnotetext{
7 Duran 2016, 2.

8 See, inter alia, Duchacek 1987 and 1990.

$9 \quad$ See, inter alia, Soldatos 1990 and 1991.

10 See Acuto 2013; Aldecoa and Keating 1999; Callanan and Tatham 2014; Duran 2011, 2016; La Porte 2013; Lecours 2002; Mamadouh 2016; Michelmann and Soldatos 199o; Tatham 2008, 2010, 2013; Gress 1996.

11 Curtis 2014.

12 See, for instance, Aldecoa and Keating 1999; Cornago 2010a; Duran 2011, 2016; Lecours 2002.

13 See, inter alia, Acuto and Rayner 2016; Acuto 2013; Van der Pluijm, with Melissen 2007; La Porte 2013; Mamadouh 2016.

14 See, for instance, Curtis 2014; Friedmann 1986; Ljungkvist 2015; Nijman 2016; Sassen 1991, 2006.
} 
of smaller localities should not be-at least theoretically—dismissed tout court. ${ }^{15}$

Endeavouring to differentiate and underscore the specificities of local actors' engagement in paradiplomatic activities, more accurate terms have been proposed such as 'urban paradiplomacy',16 'informal diplomacy,'17 'city diplomacy'18 and 'public diplomacy.' ${ }^{19}$ In this article, the notion of paradiplomacy is qualified by using the more comprehensive term municipal which, intuitively, refers to the type of diplomatic-like activities carried out by municipalities. Shying away from any attempts to either criticise the abovementioned terms or argue for the need for an alternative notion, this terminological choice hinges on the assumption that not only capital and large cities are paradiplomatic actors.

Building on the theoretical and empirical contributions on paradiplomacy, this article aims at excavating the teleology of municipal paradiplomacy, pinpointing and delving into its teloi. Since paradiplomacy is a practice mimicking state diplomacy, I identify its teloi by parallelism with the latter. Notably, state diplomacy is, on the one hand, about the mediation of antagonism and affirmation of power among sovereign actors, which strive to contain or resolve international conflicts; on the other hand, it deals with the negotiation of states' interests. Therefore, it is possible to identify the main teloi of state diplomacy in: assertion of sovereignty, bargaining of power and conflict management. However, municipal authorities, unlike states, are neither sovereign entities nor endowed of a high degree of autonomy, and thus cannot act as they wish — neither de jure nor de facto. What differentiates state diplomacy from municipal (para)diplomacy is, thus, the legal status of the entities involved in foreign affairs: while states are sovereign entities, local governments are subordinated to the latter. Therefore, alternative heuristic categories have to be developed to grapple with the intrinsic purposes of paradiplomacy.

To factor in the specificities of local authorities, this article employs the following functional equivalents: self-determination, influence and latent contention (see Fig. 1). Self-determination is here understood as the functional equivalent of sovereignty for local authorities, a notion that indicates an attempt to expand municipalities' room for manoeuvre. Self-determination aptly describes the greater freedom of municipalities to act on the international stage

15 See, for instance, the case of the network, Cultural Villages of Europe, made up of small European localities.

16 Soldatos 1991, 346.

17 Laguerre 1994, 38.

18 Acuto and Rayner 2016, 1147; Van der Pluijm, with Melissen 2007, 6.

19 La Porte 2013, 86. 


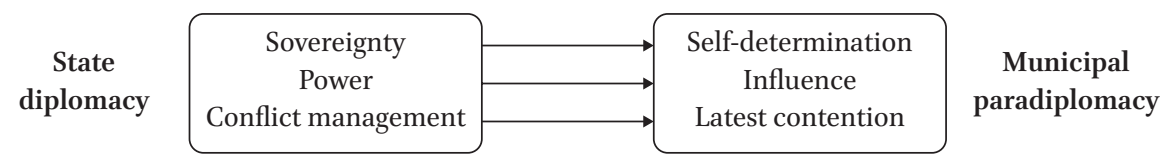

Source: Author.

FIGURE 1 State and municipal diplomacy

with no or minimal control from the central state, while taking into account how the centrifugal aspirations of local authorities are limited to the existing national constitutional and legal frameworks. Second, while state diplomacy is about consolidating state power, municipal paradiplomacy is about expanding municipalities' influence. By mobilising at the supranational level, municipalities strengthen their international political agency and partly loosen their economic dependence from the central state, thanks to the possibility of liaising directly with the EU and building up partnerships to apply for EU funding - as pointed out by the literature on this topic discussed in the ensuing sections. Finally, this article defines latent contention as an attempt to challenge the central state through processes of 'bypassing' and — to some extent-'delinking'. Although not subverting the central-local power structure, which is defined by law, paradiplomacy helps cities to be recognised as credible negotiators, becoming the counterpart of the EU in supranational decision-making and of the central state in domestic negotiations. Drawing on these three notions, this article thus provides a throughout understanding of the teleological principles of municipal paradiplomacy. In so doing, the article aims at bringing the city back into international relations.

This article proceeds as follows. After this introduction, in Section 2 a historical excursus of the main institutional processes that have enabled the development of paradiplomacy is sketched out. In Sections 3, 4 and 5 the constitutive elements of municipal paradiplomacy are illustrated. The article draws to a close with Section 6.

To better grasp the teleology of municipal paradiplomacy, a historical excursus of the institutional framework that enabled local authorities' development of paradiplomatic practices seems to be a worthy starting point.

Historical research has found that embryonic forms of what is now termed as paradiplomacy date back to Ancient Greece: accordingly, the first document referring to a type of nonofficial diplomacy appears to be Demosthenes's 'Пepi 
$\tau \eta \hat{\varsigma} \pi \alpha \rho \alpha \pi \rho \varepsilon \sigma \beta \varepsilon i \alpha \varsigma^{\prime}$ (Peri tes parapresbeia-'On the false embassy'). ${ }^{20}$ Despite that forms of paradiplomacy ante litteram were practised by ancient Greek city-states as well as by city-states in the Italian territory at the end of the $1400{ }^{, 2}{ }^{21}$ it was in the 2oth century that municipalities returned into the limelight after centuries of marginalisation. In particular, cities' political agency was consolidated by both EU-level and domestic processes that may be summarised as: the unlocking of 'window[s] of opportunity' for municipalities at the EU level, ${ }^{22}$ the devolution of administrative powers. Let us discuss these processes in detail.

\subsection{EU Opportunity Structures}

The EU opened up new avenues for European local authorities to widen their wiggle room. In particular, the subsidiarity principle, ${ }^{23}$ set out in the 1992 Treaty of Maastricht, strengthened subnational authorities' participation in the process of European integration. ${ }^{24}$ The subsidiarity principle has supported national reforms to increase competencies at the local level. Accordingly, policy issues should be addressed, whenever possible, by lower levels of authority; only if these issues have a national relevance or cannot be tackled efficiently by subnational authorities do they have to be addressed by the central government. A recent attempt to consolidate the role of cities in the EU policymaking is the Urban Agenda for the EU, which envisages 'a new form of multilevel and multi-stakeholder cooperation with the aim of strengthening the urban dimension in EU policy'.25

The participation of cities in the EU polity has also been fostered by initiatives funded by European Regional Development Funds with an urban dimension, which incentivise the establishment of networks as means to collectively tackle social, economic and environmental problems. Underlying the EU's urban-friendly attitude there has been the belief that, being the closest administrative level to the citizens, local authorities can help tackle the longstanding issue of the democratic deficit in the EU. In effect, cities 'seem to be potential local bases for the implementation of European programmes, for the mobilisation of citizens on behalf of the European integration project, and

\footnotetext{
20 As Duran 2013, 150 explains, the term parapresbeia precisely indicates a 'false embassy'.

21 Berridge 2015, 1.

22 Saunier 2008, 7.

23 Now established by the Article 5 of the Consolidated versions of the Treaty on European Union and the Treaty on the Functioning of the European Union (2010/C 83/01).

24 Ewen 2008, 108; Goldsmith 1993, 683.

25 Urban Agenda for the EU 2016, 4.
} 
for the participation of coalitions that aim to advance this project.'. ${ }^{26}$ Further, the willingness of the EU institutions to involve local authorities in policymaking has been instrumental to achieving specific objectives: on the one hand, the liaisons with European local governments has enabled the EU institutions to enhance internal cohesion; on the other hand, it has made easier to understand the perspective of local governments to improve the EU policymaking process. ${ }^{27}$

Thanks to the acquisition of more capacity to act without the interference from the central state, local authorities have been able to hone their paradiplomatic skills, mimicking nation states' praxes and behaviours in foreign policy. Paradiplomacy may be conceived — at least partly — as a tool to address the political marginalisation and the financial cutback operated by the central state. Municipalities have thus turned to the international scale in search of valuable assets such as capital, expert knowledge and connections-which the central state has not provided them with - to boost their economy and address local issues. As Soldatos stated, "The development of urban paradiplomacy is an expression of "functional sovereignty" in the face of the urgent dilemma "internationalize or perish" ${ }^{28}$ Even more trenchant is Benjamin R. Barber's argument, for whom 'cities have little choice: to survive and flourish they must remain hospitable to pragmatism and problem solving, to cooperation and networking, to creativity and innovation. ${ }^{29}$ To do so, the development of an international profile-for example, through the participation in transnational urban organisations or by hosting international events-increases the visibility of the city, which is instrumental to secure investments to subsidise welfare services and improve local infrastructures. ${ }^{30}$ Hence, the creation of 'strategic cities alliances and networks' is crucial to acquire the status of international city. ${ }^{31}$

\subsection{Decentralisation Reforms and Municipal Agency}

In addition to the opportunities provided by the EU, public administration reforms, which led to the delegation of state competencies to local authorities, incentivised the supra-national engagement of the latter. The devolution of power was reinforced by economic, political and social issues such as mounting public expenditure, crisis of the welfare state, increasing distrust of the

\footnotetext{
26 Le Galès 2002, 76.

27 Goldsmith 1993, 683.

28 Soldatos 1991, 346.

29 Barber 2013, 13.

$30 \quad$ Mocca 2017, 706.

31 Soldatos 1991, 346.
} 
national political class, the 'legitimacy crisis' of central power, and pressing requests for greater public involvement in decision-making. ${ }^{32}$ On this latter point, it has been noted that state reorganisation was also the outcome of 'bottom-up pressures' of social agents, less trustful towards the central state. ${ }^{33}$ The decentralisation process was undertaken to respond to the changing relationship between voters and the political class: in several European countries, where election turnouts were shrinking, administrative changes at the local level were pointed to as the solution to address requests for a more responsible political class and a broader political participation of citizens. ${ }^{34}$

While broadening the competencies of local governments, decentralisation was paralleled by substantial cuts to local budgets. Therefore, municipalities found themselves in need of additional funding to face mounting social and economic problems. For this, many local politicians tried 'to be local boosters, to lead development coalitions and to break free from the constraints of party hierarchies. ${ }^{35}$ Furthermore, local political leaders, less bounded by party politics, gained more room for manoeuvre to implement 'popular policies' and to make concessions to entrepreneurs and investors. ${ }^{36}$

Such 'enfranchisement' - to borrow Panayotis Soldatos and Hans Michelmann's terminology ${ }^{37}$-occurring in the political sphere was coupled with the attempt of local authorities to compete on their own on the market. As noted by William F. Lever, in the 1980 os and 1990s urban and regional governments were trying to 'delink' themselves from the national economic system. ${ }^{38}$ Lever points out four main factors that led to the disconnection between centre and periphery: a widespread belief that local governments could be more successful than national governments in managing local economy; the resurgence of the idea of 'the Europe of the regions'; the confidence of local administrators to be able to economically 'outperform' the central government-which, in turn, would ensure that they would be re-elected—and, finally, through strategies of 'urban marketing' local governments could build an urban image different from the 'national identity'. ${ }^{39}$ As a result, many cities have sought to

\footnotetext{
32 Borraz and John 2004, 108, 111.

33 Jobert 1999, in Le Galès 2002, 91.

34 Borraz and John 2004, 114-115.

35 Borraz and John 2004, 113-114.

$36 \quad$ Borraz and John 2004, 113-114.

37 Soldatos and Michelmann 1992, 132.

38 Lever 1997, 227.

39 Lever 1997, 228; 230-232 indicate Barcelona, Frankfurt and Milan as 'delinked' European cities that fared better than the average national economic performance.
} 
develop an international or European profile to establish their position within the global networks.

The lack of intervention of the central governments to address the problems faced by local authorities and the belief that cities were economically and politically more advanced than the central state soured the national-local relations and prompted cities to strengthen their linkages outside the national boundaries. As Renaud Payre and Pierre-Yves Saunier observe in their analysis of the involvement of Lyon in the Union Internationale des Villes and Eurocities, ${ }^{40}$ 'Lyon's municipal leaders tried to escape a centre-periphery relationship', in a context marked by the transfer of competencies from the central level to subnational governments and European institutions. ${ }^{41}$ Similarly, it has been noted that local authorities conceive 'networks as an opportunity to subvert centralisation strategies of the state' and to better 'represent the interests of localities' ${ }^{42}$ In the dedicated literature, it has been underscored how municipalities' subnational mobilisation, such as interurban networking, enables cities to 'bypass' central governments. ${ }^{43}$ In particular, it has been argued that in those countries where local politicians are endowed of a high 'political status', these have the room for manoeuvre to set out international strategies that may be in contrast with the national level. ${ }^{44}$ Furthermore, Harriet Bulkeley observes that the effectiveness of initiatives promoted within networks is influenced by 'the powers of municipalities, ... central-local government relations' and the capacity to "outflank" the nation-state in pursuit of their political aims and ambitions. ${ }^{45}$

\section{3}

Paradiplomacy as a Means for Municipal Self-determination

As anticipated in the introductory section, one of the first goals of state diplomacy is to assert state sovereignty. In this sense, diplomacy is thus a means for the representation of state's interests in the international arena. In effect, as G.R. Berridge and Alan James observe, diplomacy, although evolving over time, still involves 'relations between ... proud and jealous sovereign states' and its 'essence' is still about 'promoting and justifying states' interests.' ${ }^{46}$

\footnotetext{
$40 \quad$ Founded in 1913 and 1986, respectively. Payre and Saunier 2008, 70, 71.

$41 \quad$ Payre and Saunier 2008, 83.

42 Bulkeley et al. 2003, 237.

43 Ward and Williams 1997, 445; Bulkeley 2005, 893; Mocca 2018.

$44 \quad$ Kübler and Piliutyte 2007, 362.

45 Bulkeley 2005, 893 .

46 Berridge and James 2003, ix.
} 
Notably, sovereignty does not fully pertain to local authorities: sovereignty is indeed either 'vested in one authority only' - as in unitary states — or is 'carefully proscribed' ${ }^{47}$ Consequently, 'self-determination' is employed here as a functional equivalent of sovereignty. To dispel any doubt about the heuristic validity of this concept, a thorough explanation for this conceptual choice is required. In particular, I ought to justify why self-determination constitutes the functional equivalent of sovereignty, rather than other akin conceptsprimarily autonomy which, at first, may seem more appropriate.

Local autonomy has been defined as 'the ability of local governments to have an independent impact on the well-being of their citizens', the latter indicating both financial and nonfinancial resources available to individuals to fulfil their aspirations. ${ }^{48} \mathrm{~A}$ more accurate definition has been proposed by Gordon L. Clark, for which local autonomy is characterised by two types of power: 'initiation' and 'immunity'49 While 'initiation' indicates 'the actions of local governments in carrying out their rightful duties', 'immunity allows local governments to act however they wish within the limits imposed by their initiative powers'.50 As the definition provided by Clark highlights, autonomy is set out by law, which delimits local authorities' wiggle room. On closer examination, it is possible to distinguish two types of autonomy: administrative autonomy, meaning the scope and number of policy functions to which a city is entitled, and political autonomy, which indicates the possibility to directly elect political representatives. ${ }^{51}$ Therefore, due to different combinations of policy competencies and political capacity, the degree of autonomy changes both within and across countries. ${ }^{52}$ Further, more than an absolute concept (autonomous or not autonomous), autonomy can be understood as a relative concept, defined by a continuum where the two extremes are 'high autonomy' and 'low autonomy'. Consequently, autonomy is also a hierarchical concept, whereby specific cases may be positioned on the continuum for each of the types of autonomy (see Fig. 2).

In an attempt to summarise previous definitions of local autonomy, Lawrence Pratchett describes this concept as 'an issue of sovereignty—if not sovereignty over everything within a territory, then at least sovereignty over certain spheres of activity'.53 In fact, local autonomy emanates from the upper

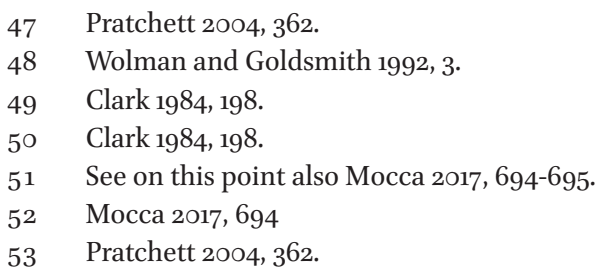




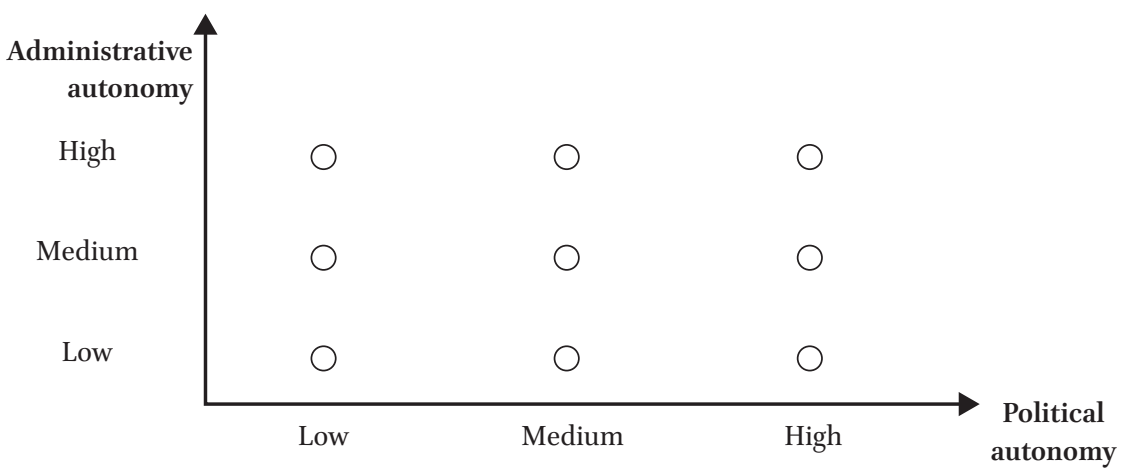

Source: Author.

FIGURE 2 The concept of autonomy

level's decision to devolve competencies, which 'can be withdrawn or altered at the whim of the sovereign power. ${ }^{54}$ To provide a comprehensive definition, Pratchett spells out local autonomy as 'freedom from higher authorities', 'freedom to achieve particular outcomes' and 'reflection of local identity'. ${ }^{55}$ The first definition emphasises the liberty enjoyed by lower levels of government, while the second underscores the opportunities available to municipalities to fulfil local needs and the last one brings out the development of 'a sense of place through political and social interaction' within a local community. ${ }^{56}$

Taking the cue from this threefold definition of local autonomy, paradiplomacy may be described as a means to achieve 'freedom to', inasmuch as it enables municipalities to deploy new instruments and methods to meet their localities' needs as they see fit. In this sense, municipalities engage in 'public diplomacy' to 'influence international political decisions that might affect city life. ${ }^{57}$ This conceptualisation of municipal paradiplomacy implicitly characterises much of the literature on transnational municipal networks. Accordingly, this stream of research highlights how taking part in Transnational Municipal Networks enhances cities' political influence, lobby capacity and problemsolving attitude and allows for knowledge sharing and network building. ${ }^{58}$ By way of contrast, paradiplomacy is less about 'freedom from': it is true

\footnotetext{
54 Pratchett 2004, 362.

55 Pratchett 2004, 363 (emphasis in original).

$56 \quad$ Pratchett 2004, 366.

$57 \quad$ La Porte 2013, 89 .

58 See, inter alia, Andonova, Betsill and Bulkeley 20o9, 63-65; Bulkeley and Betsill 2003, 2627, 52; Ewen 2008, 103, 108, 110; Heinelt and Niederhafner, 2008, 174; Kern and Bulkeley 20o9, 314-316, 319-320, 323-324, 327-328; Kübler and Piliutyte 2007, 367-370; Le Galès 2002, 106-107; Mocca 2018, 204, 217; Payre and Saunier 2008, 72, 8०, 81.
} 
that, by engaging at the supranational level, municipalities widen their political influence, but it does not make them more autonomous stricto sensu since it increases neither local authorities' policy competencies nor their legal powers. Likewise, municipal paradiplomacy does not entail the social and political relations braided within local communities since it is a prerogative of local political elites. As such, paradiplomacy is not so much about developing a truly community-driven 'sense of place', as it is often about branding and marketing local specificities to make localities more attractive to investors.

This brief rundown of the concept of local autonomy helps elucidate the first telos of municipal paradiplomacy and underscores that this practice should not be mistaken as a quest for more autonomy. In this respect, Noé Cornago points out that paradiplomacy 'suggests a contentious connection with diplomacy ... while simultaneously affirming an ambition of separate existence or autonomy'.59 With this statement, Cornago restricts paradiplomacy to regions or federal states and meso-level administrative units that, being endowed of legal capacity and significant administrative competencies, may jeopardise the unity of nation states - while cities' supranational engagement cannot pose such a threat, 'neither territorially nor simply symbolically'.60 Inarguably, Cornago's point ${ }^{61}$ reveals some truth: as cities cannot separate from a country and become independent political entities, their paradiplomatic activities are not bound to expand their autonomy — which, as already mentioned, indicates the capacity of a political entity to cater for its citizens' needs without the intervention from the upper levels of authorities. For sure, the political freedom of local authorities is constrained by the very same existence of the central state: while the latter does not assume an interventionist role in local governments' international activities, it establishes by law the perimeters within which municipalities are free to move. Nevertheless, as documented in the dedicated literature, local authorities' international mobilisation contributes to broaden their political leverage in foreign and domestic policy, carving out a space for themselves to act outside the control of the central state. ${ }^{62}$

In light of the above discussion, the term self-determination appears to be more appropriate to describe local authorities' increased capacity to act without or with limited control of the central state provided by municipal paradiplomatic activities. The use of the concept of self-determination as a 'mild' form

59 Cornago 2010b, 94.

6o Cornago 2010a, 14.

61 Cornago 2010a, 14.

62 See, inter alia, Bulkeley and Betsill, 2003, 190; Kern and Bulkeley 2009, 329; Le Galès 2002, 95; Mocca 2018, 218; Payre and Saunier 2008, 83. 


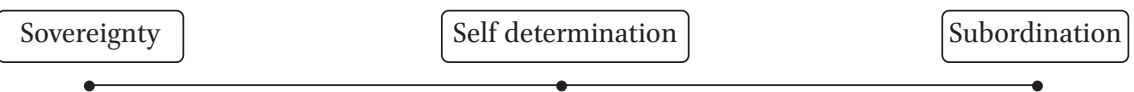

Source: Author.

FIGURE 3 Illustration of self-determination

of autonomy is ideally positioned between full independence and complete subordination, as illustrated in Fig. 3. Unlike autonomy, self-determination better frames the freedom of municipalities to act as autonomous agents in international affairs, while taking into account the national constraints within which they operate. Such a conceptualisation is also in line with Manuel Duran's interpretation of paradiplomacy as a 'complex political reality, taking a middle position between attempts to break away from the state (or sometimes even the state system), and attempts to engage in the search for communalities, economic and cultural ties with other international actors, including the state. 63

Understood as an attempt by local authorities to distance themselves from the state and thread cross-level and transnational cooperative relations, paradiplomacy thus constitutes an instrument to broaden the self-determination of local governments. More precisely, self-determination may be understood in both economic and political terms. On the one hand, paradiplomacy may provide municipalities with more opportunity to attract external investments and funding. For instance, cities' international strategies are often aimed at increasing their international profile as exemplary cities in the attempt to attract investors. ${ }^{64}$ As such, self-determination acquires the meaning of self-reliance. In other words, more room for manoeuvre provided by paradiplomatic initiatives, such as engagement in interurban networks, helps municipalities to achieve greater (but not full) economic independence, often integrating domestic and sub-national funding. ${ }^{65}$ On the other hand, paradiplomacy helps cities consolidate their political agency, by acting as the negotiating counterpart of the EU and more indirectly of the central state. ${ }^{66}$ In this sense, selfdetermination is understood as self-rule, inasmuch as, through paradiplomatic practices, municipalities act without consulting the central state, even signing binding agreements and covenants.

\footnotetext{
63 Duran 2016, 3.

64 Mocca 2017, 706; 2018, 217.

65 Mocca 2018, 210.

66 Mocca 2018, 210, 217.
} 
Ultimately, self-determination, just like autonomy and independence, is an asymmetric relational concept, inasmuch as it implies the emancipation of one agent from another, whose freedom and powers are not equal. While toning down cities' runaway aspirations, the concept of self-determination implies a latent tension between the local and central levels of authorities, as will be shown later in this article. Through their paradiplomatic repertoire, municipalities try to move away from the orbit of the state. Despite not being endowed of 'hard powers' and being restrained by state authority, municipalities mobilising at the supranational level wield political influence.

Turning now to the second telos, the analogous of state power is influence. The conceptualisation of influence as an aim of paradiplomacy can be found in the literature. For instance, according to Teresa La Porte, the (para)diplomatic instruments used by local authorities to undertake European engagement are about 'persuasion' - that is, the 'power of influence' ${ }^{67}$ Seeing influence as the functional equivalent of power does not mean that local authorities do not have powers at all. However, in foreign policy, nation states hold the hard power of coercion, while local authorities may only rely on the 'soft power' of influence which, as Joseph Nye observes, is about 'getting others to want the outcomes you want. ${ }^{\prime} 8$

To draw the line between power and influence, this article borrows Peter Morriss' theorisation that denotes power as the capacity to 'effect something', which means 'to bring about or accomplish it', and influence as the ability to 'affect something', that is 'to alter it or impinge on it in some ways'. ${ }^{69}$ Although this conceptual distinguo lends some theoretical help to clarify the purpose of municipal paradiplomacy, it is possible to add another analytical layer to better identify the third telos of paradiplomacy. As a result, power, understood as the capacity to 'effect', may be further distinguished in power as normativity and power as enactment. In its first articulation, power falls under the remit of the state's and, to some extent, regional governments' competencies, which have the power to legislate. In its second meaning, power conceived as enactment indicates the capability to intervene concretely over an issue, and rests with all levels of governments—including local authorities. This latter

$67 \quad$ La Porte $2013,86$.

68 Nye 2008, 95 .

69 Morriss 2002, 29 (emphasis in original). 
conceptualisation of power captures the 'can-do thinking' proper of local authorities, underpinning subnational mobilisation. ${ }^{70}$ In this sense, albeit not expanding the range of powers of which municipalities are entitled, paradiplomatic activities strengthen cities' capacity to act, providing them with the opportunity to create networks of peers with which to exchange policy ideas and examples that could be implemented into their localities. ${ }^{71}$

Following this line of reasoning, it could be argued that municipalities may 'affect' the decision-making process of upper levels of authority on specific issues through the soft power of persuasion-for instance, on the content of the EU legislation on urban matters or of EU funding calls. ${ }^{72}$ Therefore, municipalities exert an indirect 'effect' on power. In practical terms, municipalities wield influence by lobbying supranational organisations: ${ }^{73}$ in so doing, municipalities reproduce on a lower scale the negotiation practices proper of international diplomatic relations, thus asserting their agency as competent negotiators. Inarguably, paradiplomacy constitutes a means to bolster cities' reputation and recognition: cities proactively establish connections with other peers and supranational organisations to build their identity as credible political agents on the international chessboard. In more sophisticated terms, taking the cue from psychanalytical-like reading put forward by some diplomacy scholars, Duran recurs to the 'Self-Other binary' to explain how, even in the realm of paradiplomacy, the acknowledgment of other entities leads to the affirmation of the existence of the self. ${ }^{74}$ By assuming a proactive and vocal role at EU level, for example through interurban networks, cities seek to demonstrate that they are seriously committed to tackle social, economic and environmental urban problems, and therefore reliable political actors. ${ }^{75}$

The divergence between power and influence as teloi of state and municipal paradiplomacy, respectively, reflects the overall teleological difference between the two phenomena. In this respect, it is argued that while state diplomacy is primarily 'power play diplomacy', aimed at pursuing state's objectives, city paradiplomacy can be described as 'humanist diplomacy', devoted to the establishment of linkages among individuals. ${ }^{76}$ Furthermore, sub-state-as well as municipal-paradiplomacy is geared towards the 'management of estrangement or the mediation of separateness', seeking to pursue territorial

$\begin{array}{ll}70 & \text { Barber 2013, 6. } \\ 71 & \text { Mocca 2018, 210-211. } \\ 72 & \text { Mocca 2018, 210. } \\ 73 & \text { Mocca 2018, 204. } \\ 74 & \text { Duran 2011, 342-343. } \\ 75 & \text { Mocca 2018, 217. } \\ 76 & \text { Duran 2016, 5. }\end{array}$


aims through the enhancement of the connections with other agents. ${ }^{77}$ While trying to delink themselves from the state, paradiplomacy becomes part and parcel of a politics of relinking, allowing to forge crucial relationships with peers located in other countries, with the ultimate goal of expanding their sphere of influence outside local and national boundaries.

To sum up, paradiplomacy may be conceived as a means for local authorities to broaden their political influence, acquiring more freedom to negotiate directly with EU institutions and to pursue their territorial interests independently from the central state. For this reason, paradiplomacy may engender a contentious relationship between municipalities and the state, a point that is examined in the next section.

Just like state diplomacy, paradiplomacy is about establishing relations with a third party. Such relations may be either cooperative or more or less overtly contentious. ${ }^{78}$ As Michaël Tatham points out, two types of paradiplomacy may be discerned: 'by-passing paradiplomacy', when subnational units act alone, with no relation with the central state, and 'co-operative paradiplomacy', indicating the concerted action of subnational and national governments. ${ }^{79} \mathrm{In}$ particular, Tatham observes how bypassing paradiplomacy may engender two main reactions from the central government: on the one hand, the interaction of non-state actors at EU level with no role of the state may kindle an oppositional relation; alternatively, the autonomous subnational mobilisation may be accepted or even overlooked by the central government. ${ }^{80}$ Similarly, Mark Callanan and Michaël Tatham distinguish three forms of subnationalnational relations: 'co-operation', 'by-passing' (that is, no relation is forged) and 'conflict'.81 They suggest that extant contributions indicate that 'stronger subnational authorities' are less likely to outflank their national government as they have more leeway, finding that single local authorities are more likely to adopt a 'bypassing' attitude towards the central government. ${ }^{82}$ Further,

\footnotetext{
77 Duran 2016, 4-5.

78 Van der Pluijm with Melissen 2007, 12-13.

79 Tatham 2010, 78.

8 o Tatham 2010, 90 .

81 Callanan and Tatham 2014, 194.

82 Callanan and Tatham 2014, 194.
} 
Callanan and Tatham note that this type of subnational-national relation is a "'fall back" option' put in place when a collaborative relation is difficult. ${ }^{83}$

By way of contrast, other authors conceptualise paradiplomacy as a device for local authorities to confront the state. The relation between central states and local authorities is hierarchical and thus inevitably asymmetric, making the two sides unequal players. ${ }^{84}$ Following Duchacek and Soldatos' analysis, paradiplomacy may be framed in terms of the dichotomy 'centralization/ decentralization', 85 inasmuch as municipal paradiplomacy puts, although indirectly, local governments and the central state in a contentious relation.

The (latent) local-centre rivalry underlying paradiplomacy was already noted in the early 1990s. Soldatos and Michelmann argue that a 'growing international interdependence' - engendered by globalisation, economic liberalisation, European integration and the improvement of the communication networks-led to the 'perforation of the sovereignty of nation states' and, consequentially, to the 'international enfranchisement' of subnational territorial entities, which resulted in the development of an 'active network of paradiplomacy'. ${ }^{86}$ In this view, the international engagement of subnational units represents the third option between surrendering to globalisation and facing economic recession. ${ }^{87}$ According to Cornago, subnational actors' paradiplomatic activities are the by-product of the "pluralization" of the diplomatic realm'-engendered what the author labels as 'agonistic pluralism'.88 The 'perforation' of the international sphere by non-state actors thus transformed diplomacy, which ceased to be a 'just-state practice' and became 'a multi-actor phenomenon'. ${ }^{89}$ In this vein, 'diplomacy [was] no longer the exclusive monopoly of a monistic 'self', i.e. the central state'. 90

From a theoretical perspective, this change was captured by James Der Derian's 'post-modern' reading of paradiplomacy, thanks to which paradiplomacy came to be understood as an antagonist instrument of subnational actors against the state, intended as 'a form of diplomacy, transgressing and provoking the traditional stance on diplomacy'. ${ }^{1}$ Duran conceptualises 'subnational diplomacy' as a dual strategic choice between cooperation with and

\footnotetext{
83 Callanan and Tatham 2014, 202.

84 Elander 1991, 37.

85 Aguirre 1999, 196 (emphasis in original).

86 Soldatos and Michelmann 1992, 129, 132.

87 Soldatos and Michelmann 1992, 129-134.

88 Cornago 201ob, 91-92.

89 Duran 2013, 147.

$90 \quad$ Aguirre 1999, 201.

91 Duran 2013, 149.
} 
conflict against the central state. ${ }^{92}$ Similarly, Barber begs the question as to whether the 'interest of cities' and those of the states will be 'in harmony or in conflict', and whether cities will be allowed to keep threading cooperation networks despite nation states being 'not merely indifferent but also hostile' to their activities. ${ }^{93}$ The answer to these is questions is, according to Barber, that the ambitions of cities and states 'are often necessarily in tension', as the crossborder vocation of cities is contained by state power. ${ }^{94}$

As a third way between cooperative and contentious paradiplomacy, municipalities may also seek to find exclusive international arenas where there is no or minimum involvement of the nation states. As an example, membership in transnational municipal networks, one of the most widespread forms of municipal paradiplomatic activities, enables member cities to make their voice heard without state intermediation. More precisely, wedged in between the more or less conflictual local-centre relation is the EU, which performs the role of a 'mediator' between the two levels of authority. ${ }^{95}$ As such, cities' international networks function as an indirect channel through which to influence the central state. Echoing Liesbet Hooghe, it can be argued that nation states do not act as 'gatekeepers' that mediate between the local and supranational levels. ${ }^{96}$ In this respect, it has been shown that cities are interested primarily in influencing EU policy-making and, thus, the impact on national governments is an indirect effect of lobbying at the EU level since nation states have to implement European directives into national laws. ${ }^{97}$ Further, through peer-to-peer exchange of knowledge and experience, European cities come across effective solutions to urban problems implemented by other peers; in turn, these solutions give grounds to negotiate with the national state more capacity to address local problems. ${ }^{98}$ This argument can also be found in Payre and Saunier's premise that local governments' supranational engagement has equipped cities with 'political, intellectual, and practical resources to enable a given municipality to adjust its presence on the intermunicipal map, develop its agency within national politics, and fulfil its search for local support'.99

Such willingness of many municipalities to enfranchise themselves from the central state is not symptomatic of the 'hollowing out' of the state. Taking

\footnotetext{
92 Duran 2011, 342.

93 Barber 2013, 9.

94 Barber 2013, 9-10.

95 Mocca 2018, 210.

96 Hooghe 1995, 177 .

97 Mocca 2018, 210, 217.

98 Mocca 2018, 211.

$99 \quad$ Payre and Saunier 2008, 73.
} 
forward Barber's theory of a world parliament of mayors, Simon Curtis argues that the cooperative networks in which many cities worldwide are engaged cannot be seen as only 'a challenge to the state', in that a growing influence of cities does not correspond to the decline of central states. ${ }^{100}$ For the author, this phenomenon does not prove the fall of the state per se, but the demise and restructuring of 'a particular historical iteration of the state- the nationstate' - paralleled by the growing influence of the 'Global City' as a 'new historically distinctive form of the city' ${ }^{101}$ While this holds true, recent changes in the political landscape in Europe - and even beyond - hint at an international order stirred up by the attempt of nation states to regain control of their dispersed power, showing how the decentralisation trend may be reversed.

\section{Discussion and Conclusion}

This article has sought to provide a theoretical contribution to the literature analysing the role of municipalities in International Relations, by grappling with municipal paradiplomacy as a salient political phenomenon characterising contemporary international affairs. By employing functional equivalents of state diplomacy's aims, this article has endeavoured to examine the teleology of municipal paradiplomacy through the identification and excavation of its three main teloi: self-determination, influence and latent contention.

As discussed previously, municipal paradiplomacy constitutes an instrument to widen cities' self-determination, inasmuch as it increases local authorities' opportunities to act with no or little control of the central state. Such greater freedom to act may be political and economic. Municipalities acquire political self-rule whenever engaged in negotiations with upper levels of authority as well as with their peers. In this sense, municipalities seek to widen their sphere of influence, inasmuch as, by being recognised as credible 'broker[s],'102 they are capable of steering decision-making in a favourable way. This recognition of the international agency of cities by third parties may also heighten economic self-reliance. In effect, paradiplomacy helps cities to place themselves on the global market.

As a corollary of the greater self-determination and influence, paradiplomacy also has implications on centre-local relations: cities develop direct linkages with other cities and the EU institutions without the interposition of nation

\footnotetext{
10 Curtis 2016, $45^{6 .}$

101 Curtis 2016, 456.

102 Duran 2016, 1.
} 
states, stretching the relationship of subordination to the central state. ${ }^{103} \mathrm{On}$ the one hand, local authorities, embedded in a growingly pluralistic system of international relations, have acquired significant international stance and established themselves as paradiplomatic actors. As such, it appears that state authority is being worn away by an ever-growing plethora of non-state agents. ${ }^{104}$ Even diplomacy, as discussed before, has become a realm where the state is not the only actor. For this, some authors have theorised the concept of 'network diplomacy', describing the creation by non-state agents of a 'diplomatic community' parallel to the one formed by states. ${ }^{105,106}$ On the other hand, the revamped wave of nationalism, witnessed by the recent rise of nationalist parties in Europe (as well as elsewhere), is reasserting the centrality of the nation state as the primary actor in international relations. In this view, the nation state is—borrowing James A. Caporaso's ${ }^{107}$ words-'a distinctive form of organization based on carving up the world into territorially exclusive enclaves. Sovereignty, in its modern form, is the right to exclude-people, capital, ideas, foreign powers, and so on'.

Against this backdrop, paradiplomacy, albeit reducing state sovereignty, may be seen as entrenched in the Westphalian form of state, as some scholars argue. ${ }^{108}$ In effect, despite threading cooperative networks that may 'influence the global economy and bypass the rules and regulations of states', local authorities' capacity to act freely is legally set out. ${ }^{109}$ In this respect, Barber prophesises that

The interdependence of cities may erode their ties to nation-states and draw them toward collaboration with one another, but no state worth its salt, as measured by its sovereignty, will stand still and watch cities annul subsidiarity and escape the gravitational pull of their sovereign mother ship. ${ }^{110}$

Therefore, European local authorities' influence, capacity to 'outflank' the central state ${ }^{111}$ and self-determination do not prove their progressive delinking

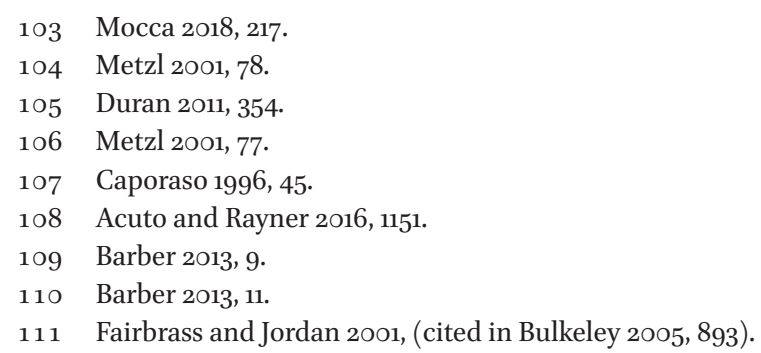


from the national level. As Barber puts it, 'Legislative sovereignty and budget authority give states plenty of ways to block run-away towns.'12 Similarly, it is true that, as Tanja Börzel and Thomas Risse point out, even non-top-down relations do not occur completely outside of hierarchy. ${ }^{113}$ Likewise, in the multitiered EU architecture, municipalities do not shy away from the weight of hierarchy. Notably, the multi-level governance framework emphasises the importance of a new mode of governing characterised by different actors across different scales interwoven in a complex web of relations. Liesbet Hooghe and Gary Marks liken multi-level governance to the famous Escher's web of stairs, describing it as a system where 'there is no up or under, no lower or higher, no dominant class of actor; rather, a wide range of public and private actors compete or collaborate in shifting coalitions.'114 However, the wiggle room of such a swath of actors is actually limited to those competences enshrined in national legislation. ${ }^{115}$ Therefore, rather than an entanglement of endless staircases, the EU architecture appears to be a much more neatly designed structure with a clear and recognisable summit. This picture resonates with Duchacek's rendition of paradiplomacy, whereby: 'Diagramatically, the nation state qua multivocal actor could be illustrated in the form of a stepped Saqqara pyramid, with its separate yet interconnected points of entry on the international scene, in contrast to the neat, single apex of the Cheops pyramid'.116

Hence, the coexistence of state diplomacy and municipal paradiplomacy witnesses the struggle between two 'forms of states':117,118,119 the first type, labelled 'post-modern', is networked, decentralised and one where power is devolved and dispersed; the second is the 'Westphalian state', the Leviathan, where power is centralised and sovereignty is not shared with any other sub- or supranational entities. ${ }^{120}$ While forecasting whether and which of these two forms will prevail would be a daunting task, this article submits that paradiplomacy, as a long-established practice, signals the enduring endeavour of several municipalities to progressively free themselves from the grip of the nation state.

\footnotetext{
112 Barber 2013, 8.

113 Börzel and Risse 2010, 116.

114 Hooghe and Marks 2001, 7, cited in Bulkeley and Betsill 2003, 28.

115 Mocca 2018, 211.

116 Duchacek 1986, cited in Aguirre 1999, 189.

117 Caporaso 1996, 30-31.

118 Cox 1983, cited in Caporaso 1996, 31.

119 Cox 1986, cited in Caporaso 1996, 31.

120 Caporaso 1996, 30, 34-35, 45.
} 


\section{Bibliography}

Acuto, Michele. Global Cities, Governance and Diplomacy: The Urban Link (London: Routledge, 2013).

Acuto, Michele and Steve Rayner. 'City Networks: Breaking Gridlocks or Forging (New) Lock-Ins?' International Affairs 92 (5) (2016), 1147-1166.

Aguirre, Iñaki 'Making Sense of Paradiplomacy? An Intertextual Enquiry about a Concept in Search of a Definition'. Regional and Federal Studies 9 (1) (1999), 185-209.

Aldecoa, Francisco and Michael Keating. Paradiplomacy in Action: The Foreign Relations of Subnational Governments (London: Routledge, 2013).

Andonova, Liliana B., Michele M. Betsill, and Harriet Bulkeley. 'Transnational Climate Governance'. Global Environmental Politics 9 (2) (2009), 52-73.

Barber, Benjamin R. If Mayors Ruled the World: Dysfunctional Nations, Rising Cities (New Haven: Yale University Press, 2013).

Berridge, G.R. Diplomacy: Theory and Practice (Basingstoke: Palgrave Macmillan, 2015).

Berridge, G.R. and Alan James. A Dictionary of Diplomacy, 2nd ed. (Basingstoke: Palgrave Macmillan, 2003).

Borraz, Olivier and Peter John. 'The Transformation of Urban Political Leadership in Western Europe'. International Journal of Urban and Regional Research 28 (1) (2004), 107-120.

Börzel, Tanja A. and Thomas Risse. 'Governance without a State: Can It Work?' Regulation and Governance 4 (2) (2010), 113-134.

Bulkeley, Harriet 'Reconfiguring Environmental Governance: Towards a Politics of Scales and Networks'. Political Geography 24 (8) (2005), 875-902.

Bulkeley, Harriet and Michele M. Betsill. Cities and Climate Change:Urban Sustainability and Global Environmental Governance (New York: Routledge, 2003).

Bulkeley, Harriet, Anna Davies, Bob Evans, David Gibbs, Kristine Kern, and Kate Theobald. 'Environmental Governance and Transnational Municipal Networks in Europe'. Journal of Environmental Policy and Planning 5 (3) (2003), 235-254.

Callanan, Mark and Michaël Tatham. 'Territorial Interest Representation in the European Union: Actors, Objectives and Strategies'. Journal of European Public Policy 21 (2) (2014), 188-210.

Caporaso, James A. 'The European Union and Forms of State: Westphalian, Regulatory or Post-Modern?' JCMS: Journal of Common Market Studies 34 (1) (1996), 29-52.

Clark, Gordon L. 'A Theory of Local Autonomy'. Annals of the Association of American Geographers 74 (2) (1984), 195-208.

Cornago, Noé. 'On the Normalization of Sub-State Diplomacy'. The Hague Journal of Diplomacy 5 (1-2) (2010a), 11-36. 
Cornago, Noé. 'Perforated Sovereignties, Agonistic Pluralism and the Durability of (Para) Diplomacy'. In Sustainable Diplomacies, eds. Costas M. Constantinou and James Der Derian (London: Palgrave Macmillan, 2010b), 89-108.

Cox, Robert W. 'Gramsci, Hegemony and International Relations: An Essay in Method'. Millennium 12 (2) (1983), 162-175.

Cox, Robert W. 'Social Forces, States, and World Orders: Beyond International Relations Theory'. In Neorealism and Its Critics, ed. Robert Owen Keohane (New York: Columbia University Press, 1986), 204-254.

Curtis, Simon, ed. The Power of Cities in International Relations (New York: Routledge, 2014).

Curtis, Simon 'Cities and Global Governance: State Failure or a New Global Order?' Millennium 44 (3) (2016), 455-477.

Duchacek, Ivo D. 'Toward a Typology of New Subnational Governmental Actors in International Relations'. Working Paper No. 87-2 (Berkeley: Institute of Governmental Studies, University of California, 1987).

Duchacek, Ivo D. 'Perforated Sovereignties: Towards a Typology of New Actors in International Relations'. In Federalism and International Relations: The Role of Subnational Units, eds. Hans J. Michelmann and Panayotis Soldatos (Oxford: Oxford University Press, 1990), 1-33.

Duran, Manuel. 'French Regions as Diplomatic Actors: The Case of Provence-AlpesCôte d'Azur'. French Politics 9 (4) (2011), 339-363.

Duran, Manuel. 'An Archaeology of Mediterranean Diplomacy: The Evidence of Paradiplomacy'. International Journal of Euro-Mediterranean Studies 5 (2) (2013), 147-158.

Duran, Manuel. 'Paradiplomacy as a Diplomatic Broker: Between Separating Differences and Engaging Commonalities'. Brill Research Perspectives in Diplomacy and Foreign Policy 1 (3) (2016), 1-56.

Elander, Ingemar. 'Analysing Central-Local Government Relations in Different Systems: A Conceptual Framework and Some Empirical Illustrations'. Scandinavian Political Studies 14 (1) (1991), 31-58.

Ewen, Shane. "Transnational municipalism" in a Europe of "Second Cities": Rebuilding Birmingham with Municipal Networks'. In Another Global City: Historical Explorations into the Transnational Municipal Moment 1850-2000, eds. Pierre-Yves Saunier and Shane Ewen (Basingstoke: Palgrave Macmillan, 2008), 69-85.

Friedmann, John. 'The World City Hypothesis'. Development and Change 17 (1986), 69-83. Goldsmith, Mike. 'The Europeanisation of Local Government'. Urban Studies 30 (4-5) (1993), 683-699.

Gress, Franz. 'Interstate Cooperation and Territorial Representation in Intermestic Politics'. Publius: The Journal of Federalism 26 (1) (1996), 53-72. 
Heinelt, Hubert and Stefan Niederhafner. 'Cities and Organized Interest Intermediation in the EU Multi-Level System'. European Urban and Regional Studies 15 (2) (2008), 173-187.

Hooghe, Liesbet. 'Subnational Mobilisation in the European Union'. West European Politics 18 (3) (1995), 175-198.

Hooghe, Liesbet and Gary Marks. 'Types of Multi-Level Governance'. European Integration Online Papers (EIoP) 5 (11) (2001).

Jobert, Bruno. 'L'Ètat en interaction'. L’Année de la Régulation 3 (1999), 77-98.

Kern, Kristine. 'Cities in a European Setting'. Paper presented at the conference 'Innovation for Good Local and Regional Governance: A European Challenge', University of Twente (Enschede), April 2009.

Kern, Kristine and Harriet Bulkeley. 'Cities, Europeanization and Multi-Level Governance: Governing Climate Change through Transnational Municipal Networks'. Journal of Common Market Studies 47 (2) (2009), 309-332.

Kübler, Daniel and Jolita Piliutyte. 'Intergovernmental Relations and International Urban Strategies: Constraints and Opportunities in Multilevel Polities'. Environment and Planning C: Government and Policy 25 (3) (2007), 357-373.

Laguerre, Michel S. The Informal City (New York: St. Martin's Press, 1994).

La Porte, Teresa. 'City Public Diplomacy in the European Union'. In European Public Diplomacy: Soft Power at Work, eds. Mai'a K. Davis Cross and Jan Melissen (New York: Palgrave Macmillan, 2013), 85-111.

Lecours, André. 'Paradiplomacy: Reflections on the Foreign Policy and International Relations of Regions'. International Negotiation 7 (1) (2002), 91-114.

Le Galès, Patrick. European Cities: Social Conflicts and Governance (Oxford: Oxford University Press, 2002).

Le Galès, Patrick and Alan Harding. 'Cities and States in Europe'. West European Politics 21 (3) (1998), 120-145.

Lever, William F. 'Delinking Urban Economies: The European Experience'. Journal of Urban Affairs 19 (2) (1997), 227-238.

Ljungkvist, Kristin. The Global City 2.o: From Strategic Site to Global Actor (New York: Routledge, 2015).

Mamadouh, Virginie. 'Town Twinning over the (Ir)relevance of the Paradiplomacy of European Cities'. In Urban Europe: Fifty Tales of the City, eds. Virginie Mamadouh and Anne van Wageningen (Amsterdam: Amsterdam University Press, 2016), 339-346.

Metzl, Jamie F. 'Network Diplomacy'. Georgetown Journal of International Affairs 2 (1) (2001), 77-87.

Michelmann, Hans and Panayotis Soldatos. Federalism and International Relations: The Role of Sub-National Units (Oxford: Clarendon Press, 199o).

Mocca, Elisabetta. 'City Networks for Sustainability in Europe: An Urban-Level Analysis'. Journal of Urban Affairs 39 (5) (2017), 691-710. 
Mocca, Elisabetta. 'Pragmatism or Idealism? An Urban Perspective onto the Politics of Interurban Cooperation for Sustainability in the EU'. Urban Research and Practice, 11(3) (2018), 200-222.

Morriss, Peter. Power: A Philosophical Analysis (Manchester: Manchester University Press, 2002).

Nijman, Janne. 'Renaissance of the City as Global Actor: The Role of Foreign Policy and International Law Practices in the Construction of Cities as Global Actors'. In The Transformation of Foreign Policy: Drawing and Managing Boundaries from Antiquity to the Present, eds. Gunther Hellmann, Andreas Fahrmeir and Miloš Vec (Oxford: Oxford University Press, 2016), 209-239.

Nye, Joseph S. Jr. 'Public Diplomacy and Soft Power'. The Annals of the American Academy of Political and Social Science 616 (1) (2008), 94-109.

Payre, Renaud and Pierre-Yves Saunier. 'A City in the World of Cities: Lyon and Municipal Associations in the 2oth Century'. In Another Global City: Historical Explorations into the Transnational Municipal Moment 1850-2000, eds. P.-Y. Saunier and S. Ewen (Basingstoke: Palgrave Macmillan, 2008), 69-85.

Pratchett, Lawrence. 'Local Autonomy, Local Democracy and the "New Localism"'. Political Studies 52 (2) (2004), 358-375.

Sassen, Saskia. The Global City: New York, London, Tokyo (Princeton: Princeton University Press, 1991).

Sassen, Saskia. Territory, Authority, Rights: From Medieval to Global Assemblages (Princeton: Princeton University Press, 2006).

Saunier, Pierre-Yves. 'Introduction Global City, Take 2: A View from Urban History'. In Another Global City: Historical Explorations into the Transnational Municipal Moment 1850-2000, eds. P.-Y. Saunier and S. Ewen (Basingstoke: Palgrave Macmillan, 2008), 1-18.

Saunier, Pierre-Yves and Shane Ewen. Another Global City (New York: Palgrave Macmillan, 2008).

Schultze, Claus J. 2003. 'Cities and EU Governance: Policy-Takers or Policy-Makers?' Regional and Federal Studies 13 (1) (2003), 121-147.

Soldatos, Panayotis. 'An Explanatory Framework for the Study of Federated States as Foreign-Policy Actors'. In Federalism and International Relations: The Role of Subnational Units, eds. Hans J. Michelmann and Panayotis Soldatos (Oxford: Clarendon Press, 1990), 34-53.

Soldatos, Panayotis 'Strategic Cities Alliances: An Added Value to the Innovative Making of an International City'. Ekistics 58 (350-351) (1991), 346-35o.

Soldatos, Panayotis and Hans J. Michelmann. 'Subnational Units' Paradiplomacy in the Context of European Integration'. Journal of European Integration 15 (2-3) (1992), 129-134. 
Tatham, Michaël. 'Going Solo: Direct Regional Representation in the European Union'. Regional and Federal Studies 18 (5) (2008), 493-515.

Tatham, Michaël. 2010. 'With or without You'? Revisiting Territorial State-Bypassing in EU Interest Representation'. Journal of European Public Policy 17 (1) (2010), 76-99.

Tatham, Michaël. 'Paradiplomats against the State: Explaining Conflict in State and Sub-State Interest Representation in Brussels'. Comparative Political Studies 46 (1) (2013), 63-94.

Urban Agenda for the EU. 'Pact of Amsterdam'. Agreed at the Informal Meeting of EU Ministers Responsible for Urban Matters, Amsterdam, The Netherlands, 30 May 2016.

Van der Pluijm, R. with Jan Melissen. 'City Diplomacy: The Expanding Role of Cities in International Politics'. Clingendael Diplomacy Papers No. 10 (Clingendael: Netherlands Institute of International Relations Clingendael, 2007).

Ward, S. and R. Williams. 'From Hierarchy to Networks? Sub-Central Government and EU Urban Environment Policy'. JCMS: Journal of Common Market Studies 35 (3) (1997), 439-464.

Wolman, H. and M. Goldsmith. Urban Politics and Policy: A Comparative Approach (Cambridge: Blackwell, 1992).

\section{Elisabetta Mocca}

is a Postdoctoral University Assistant at the Department of Sociology, University of Vienna. Her research focuses on urban politics and policy, transnational municipalism and postgrowth politics. She has published articles in international peer-reviewed journals, including Antipode, The Journal of Political Ideologies, The Journal of Urban Affairs and Urban Research and Practice. 